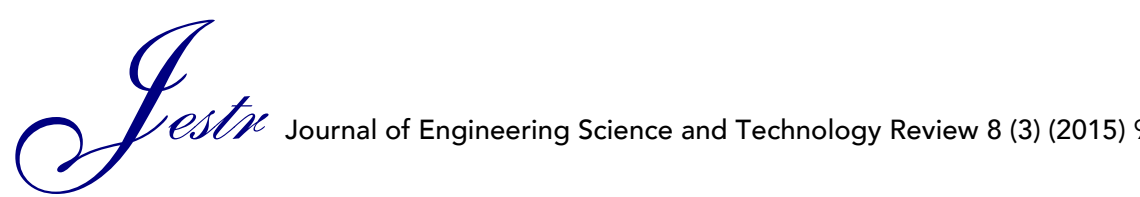

Review Article
JOURNAL OF $-111$

\title{
Solutions for Energy Efficient and Sustainable Heating of Ventilation Air: A Review
}

\author{
A. Žandeckis*, K. Kḷaviņa, M. Dzikēvičs, V. Kirsanovs and G. Žogla \\ Institute of Energy Systems and Environment, Faculty of Power and Electrical Engineering, \\ Riga Technical University, Kronvalda Blvd 1-10, Riga, Latvia, LV-1010
}

Received 12 January 2015; Accepted 21 October 2015

\begin{abstract}
A high energy efficiency and sustainability standards defined by modern society and legislation requires solutions in the form of complex integrated systems. The scope of this work is to provide a review on technologies and methods for the heating of ventilation air as a key aspect for high energy and environmental performance of buildings located in a cold climate. The results of this work are more relevant in the buildings where space heating consumes a significant part of the energy balance of a building, and air exchange is arranged in an organized manner. A proper design and control strategy, heat recovery, the use of renewable energy sources, and waste heat are the main aspects which must be considered for efficient and sustainable ventilation. This work focuses on these aspects. Air conditioning is not in the scope of this study.
\end{abstract}

Keywords: Ventilation, Air heating, Recuperation, Ventilation control, Heat pump, PCM, Solar energy, Passive design

\section{Introduction}

The necessity of good quality air ventilation is supported by numerous studies. A comprehensive literature review discussing the risks of poor ventilation; for instance, sick building syndrome, discomfort, health effects and decreasing productivity, has been completed by Dimitroulopoulou [1]. The role of a ventilation system is to remove the indoor air contaminants, like $\mathrm{CO}_{2}$, moisture and odors, and to supply fresh air to the building [2]. If the ventilation air change rate is insufficient, the indoor air quality drops. Ventilation rate measurements in European dwellings were also gathered in the review completed by Dimitroulopoulou [1], they led to the conclusion that European dwellings often encounter poor ventilation, below $0.5 \mathrm{~h}-1$, the standard in many European countries. It points to the necessity of implementing organized ventilation systems that would support improved indoor air quality. Also, in cold climates, a varying air exchange rate causes a great influence on a building's energy performance due to the need for the fresh incoming outdoor air to be heated, and the indoor heat gains are partly lost with the exhaust air [2].

According to the EU directive 2010/31/EU on the energy performance of buildings from the $31^{\text {st }}$ December 2020, all new buildings will have to be nearly-zero energy buildings [3]. For example in Latvia, nearly-zero energy buildings are defined in the Regulations of the Cabinet of Ministers Nr. 383 (09.07.2013.) on building energy certification [4]. A building can be called a nearly-zero energy building if the following, among other, conditions are fulfilled - high efficiency heat recuperation (at least $75 \%$ ) from ventilation

* E-mail address: aivars.zandeckis@rtu.lv ISSN: 1791-2377 @ 2015 Kavala Institute of Technology. All rights reserved. is used and at least a part of the building's energy consumption is covered by renewable energy sources. This means that all the buildings that will be built starting from 2020 will have to have mechanical ventilation systems with heat recuperation from ventilation, and all the buildings will have to use renewable energy sources, such as direct and indirect solar energy, wind power, bioenergy, and geothermal energy [5]. Therefore, it is necessary to understand what technologies and solutions are the available for ventilation air heating as this is a key aspect for sustainable and energy efficient buildings in a cold climate. The goal of this study is to provide a review of the technologies and methods for energy efficiency and the sustainable heating of ventilation air.

There are two fundamentally different ways of heating ventilation air - passive heating, which utilizes freely available heat; and active air heating, which supplies additional energy. Conventionally, active heating mostly depends on fossil energy consumption, whether it be electricity or centralized heating produced from fossil fuels. This review is focused on active and passive technologies and solutions developed for ventilation air heating. A review of the technologies and strategies for energy-efficient air conditioning, focusing on hot and humid climate conditions, has recently been completed by Chua et al. [6], but it does not cover ventilation air heating, which is a major issue for colder climates.

\section{Materials and Technologies for Passive Heat Utilization and Recuperation}

\subsection{Technologies for heat recovery/recuperation}

Heat recovery or recuperation is the process when heat from the exhaust air flow is transferred to the supply air flow. Most of the devices for heat recovery are not able to transfer 
mass between air flows. This reduces the recovery potential of the sensible heat (A. Mardiana-Idayu, 2012). There are several types of heat exchangers available for heat recovery fixed-plate, heat pipe, rotary wheel, and run-around (see Fig. $1)$.

Table 1.Recent reviews on related topics (not analyzed in this article)

\begin{tabular}{|c|c|c|c|c|}
\hline $\begin{array}{l}\text { Related } \\
\text { field }\end{array}$ & Topic (year) & Author (-s) & Sub-topics & Ref. \\
\hline \multirow[t]{3}{*}{$\begin{array}{l}\text { Passive } \\
\text { solar } \\
\text { design }\end{array}$} & $\begin{array}{l}\text { Optimization } \\
\text { of passive solar } \\
\text { design } \\
\text { strategies: A } \\
\text { review (2013) }\end{array}$ & $\begin{array}{l}\text { S. } \\
\text { Stevanović }\end{array}$ & $\begin{array}{l}\text { Optimization } \\
\text { methods for } \\
\text { passive solar } \\
\text { design } \\
\text { Optimization of } \\
\text { particular design } \\
\text { strategies } \\
\text { Whole building } \\
\text { passive solar } \\
\text { design } \\
\text { optimization }\end{array}$ & {$[7]$} \\
\hline & $\begin{array}{l}\text { Review of } \\
\text { passive solar } \\
\text { heating and } \\
\text { cooling } \\
\text { technologies } \\
(2010)\end{array}$ & $\begin{array}{l}\text { H.Y. Chan, } \\
\text { S.B. Riffat, } \\
\text { J. Zhu }\end{array}$ & $\begin{array}{l}\text { Trombe wall. } \\
\text { solar chimney and } \\
\text { Unglar roof } \\
\text { transpared } \\
\text { façade }\end{array}$ & {$[8]$} \\
\hline & $\begin{array}{l}\text { Trombe walls: } \\
\text { A review of } \\
\text { opportunities } \\
\text { and challenges } \\
\text { in research and } \\
\text { development } \\
(2012)\end{array}$ & $\begin{array}{l}\text { O. Saadatian, } \\
\text { K. Sopian, } \\
\text { C.H. Lim, N. } \\
\text { Asim, M.Y. } \\
\text { Sulaiman }\end{array}$ & $\begin{array}{l}\text { Different } \\
\text { configurations of } \\
\text { trombe walls } \\
\text { Efficiency } \\
\text { analyses }\end{array}$ & {$[9]$} \\
\hline \multirow[t]{2}{*}{$\begin{array}{l}\text { Solar } \\
\text { thermal }\end{array}$} & $\begin{array}{l}\text { A review of } \\
\text { solar collectors } \\
\text { and thermal } \\
\text { energy storage } \\
\text { in solar thermal } \\
\text { applications } \\
\text { (2013) }\end{array}$ & $\begin{array}{l}\text { T. Tian } \\
\text { C. Y. Zhao }\end{array}$ & $\begin{array}{l}\text { Types of solar } \\
\text { collectors, solar } \\
\text { thermal energy } \\
\text { storage, an } \\
\text { overview of } \\
\text { existing and future } \\
\text { solar power } \\
\text { stations }\end{array}$ & {$[10]$} \\
\hline & $\begin{array}{l}\text { Solar systems } \\
\text { and their } \\
\text { integration } \\
\text { with heat } \\
\text { pumps: a } \\
\text { review (2014) }\end{array}$ & $\begin{array}{l}\text { R.S. Kamel } \\
\text { A.S. Fung }\end{array}$ & $\begin{array}{l}\text { Solar thermal } \\
\text { collectors and } \\
\text { Photovoltaic- } \\
\text { Thermal collectors } \\
\text { and their } \\
\text { integration with } \\
\text { heat pumps. }\end{array}$ & [11] \\
\hline $\begin{array}{l}\text { Heat } \\
\text { pumps }\end{array}$ & $\begin{array}{l}\text { A review of } \\
\text { chemical heat } \\
\text { pumps, } \\
\text { thermodynamic } \\
\text { cycles and } \\
\text { thermal energy } \\
\text { storage } \\
\text { technologies } \\
\text { for low grade } \\
\text { heat utilization } \\
(2013)\end{array}$ & $\begin{array}{l}\text { C.W. Chan } \\
\text { J. Ling-Chin } \\
\text { A.P. Roskilly }\end{array}$ & $\begin{array}{l}\text { Adsorption and } \\
\text { Absorption cycles } \\
\text { Organic Rankine, } \\
\text { Supercritical } \\
\text { Rankine and } \\
\text { Trilateral cycles } \\
\text { Sensible thermal } \\
\text { energy storage and } \\
\text { latent thermal } \\
\text { energy storage }\end{array}$ & [12] \\
\hline & $\begin{array}{l}\text { Geothermal } \\
\text { heat pump } \\
\text { systems: Status } \\
\text { review and } \\
\text { comparison } \\
\text { with other } \\
\text { heating options } \\
(2013)\end{array}$ & $\begin{array}{l}\text { S.J Self } \\
\text { B.V. Reddy } \\
\text { M.A. Rosen }\end{array}$ & $\begin{array}{l}\text { Heat pump } \\
\text { technology, earth } \\
\text { connections, } \\
\text { current world } \\
\text { status and recent } \\
\text { developments } \\
\text { Geothermal } \\
\text { technology and } \\
\text { conventional } \\
\text { heating system } \\
\text { comparison }\end{array}$ & [13] \\
\hline & $\begin{array}{l}\text { General review } \\
\text { of ground- } \\
\text { source heat } \\
\text { pump systems } \\
\text { for heating and }\end{array}$ & $\begin{array}{l}\text { I. Sarbu } \\
\text { C. } \\
\text { Sebarchievici }\end{array}$ & $\begin{array}{l}\text { Ground-source } \\
\text { heat pump } \\
\text { systems } \\
\text { development, } \\
\text { description and }\end{array}$ & [14] \\
\hline
\end{tabular}

\begin{tabular}{|c|c|c|c|c|}
\hline & $\begin{array}{l}\text { cooling of } \\
\text { buildings } \\
(2014)\end{array}$ & & $\begin{array}{l}\text { operation } \\
\text { principle. }\end{array}$ & \\
\hline \multirow[t]{3}{*}{$\begin{array}{l}\mathrm{PCM} \\
\text { for free } \\
\text { cooling }\end{array}$} & $\begin{array}{l}\text { Phase change } \\
\text { material } \\
\text { (PCM) storage } \\
\text { for free cooling } \\
\text { of buildings - } \\
\text { A review } \\
\text { (2013) }\end{array}$ & $\begin{array}{l}\text { A. Waqas } \\
\text { Z.U. Din }\end{array}$ & $\begin{array}{l}\text { Passive (free) } \\
\text { cooling: } \\
\text { techniques and } \\
\text { principles } \\
\text { Use of PCM for } \\
\text { free cooling, } \\
\text { progress in R\&D, } \\
\text { technical design } \\
\text { and applications }\end{array}$ & [15] \\
\hline & $\begin{array}{l}\text { Phase change } \\
\text { materials } \\
\text { integrated in } \\
\text { building walls: } \\
\text { a state of the } \\
\text { art review } \\
(2014)\end{array}$ & S. A. Memon & $\begin{array}{l}\text { Determination and } \\
\text { description of } \\
\text { PCM properties }\end{array}$ & [16] \\
\hline & $\begin{array}{l}\text { Solar dryers } \\
\text { with PCM as } \\
\text { energy storage } \\
\text { medium: A } \\
\text { review (2014) }\end{array}$ & $\begin{array}{l}\text { S.M. Shalaby } \\
\text { M.A. Bek, } \\
\text { A.A. El- } \\
\text { Sebaii }\end{array}$ & $\begin{array}{l}\text { PCM as an energy } \\
\text { storage medium. } \\
\text { Methods for } \\
\text { improving the } \\
\text { thermal } \\
\text { conductivity of the } \\
\text { PCM. }\end{array}$ & [17] \\
\hline
\end{tabular}

The fixed-plate heat recovery is a very simple and widely used technology. The structure of fixed-plate heat exchangers is based on several thin plates fixed together to separate internal air flows. In regards to the air flow arrangement, there are three types of fixed-plate exchangers: counter-flow, cross-flow, and parallel flow [19]. The typical efficiency of a fixed-plate heat recovery is in the range of $50-80 \%$ [19].

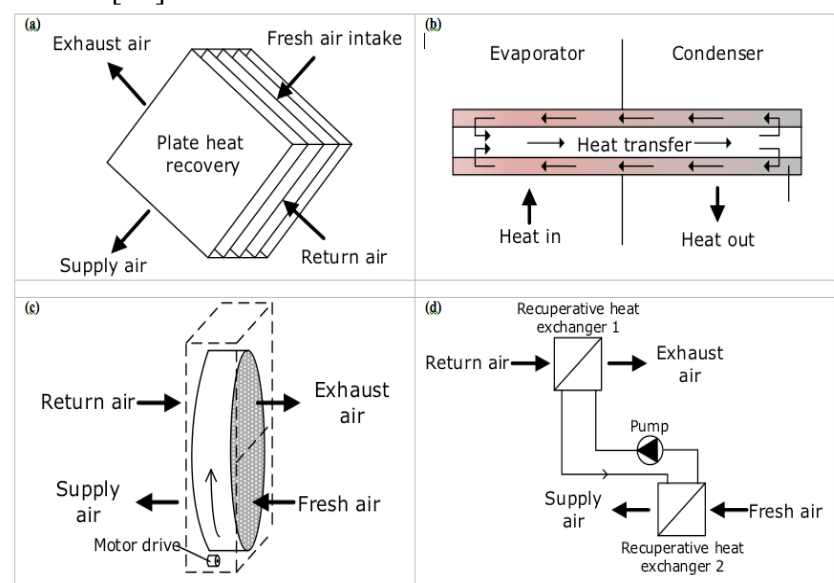

Fig. 1. Types of heat exchangers available for heat recovery. Reproduced from [18]. (a) Fixed-plate heat exchanger, (b) heat pipe, (c) rotary wheel recovery and (d) run-around system.

Heat pipe recovery is a technology based on the evaporation and condensation of a working fluid in a closed volume. The typical efficiency of heat-pipes is in the range of $43-50 \%$ [20;21]. Rotary wheel heat exchangers consist of a cylindrical porous structure with sufficient thermal inertia to absorb and transfer heat between hot and cold air streams. Because of its reliability and high efficiency (typically above $80 \%$ [22]) this type of heat recovery is very popular. However, this technology cannot provide a complete separation of air flows. This puts limitations on its application in heavily contaminated environments. In a runaround heat recovery system, the heat transfer is organized by a liquid circulating between separated air-to-liquid heat exchangers [23]. The thermal efficiency of this system is usually between $45 \%$ and $65 \%$ [18]. 
The heat exchangers for the above mentioned heat recovery systems are typically built from copper, aluminum, or steel [24]. In some cases, heat exchangers made from metal cannot be used. Therefore, there is a need for new materials to be used in the construction of heat exchangers. One of the possible solutions is the use of polymers and composite materials. Monolithic polymers, as well as polymer matrix composite materials, are used in the making of heat exchangers providing a wide range of unique properties and advantages in comparison with monolithic materials [24]. Detailed research on composite materials for use in heat exchangers has been completed by several authors [25] [26] [27].

Research by Liu et al. [28] has been carried out on totalheat recovery ventilation using poly (vinyl chloride)/sodium montmorillonite $\left(\mathrm{Na}^{+}-\mathrm{MMT}\right)$ hybrid membranes with $\mathrm{Na}^{+}-$ MMT content (see Fig. 2). Based on good moisture and heat transfer properties coupled with low air penetration, the authors made new membranes with the highest potential to be used for total-heat exchange.

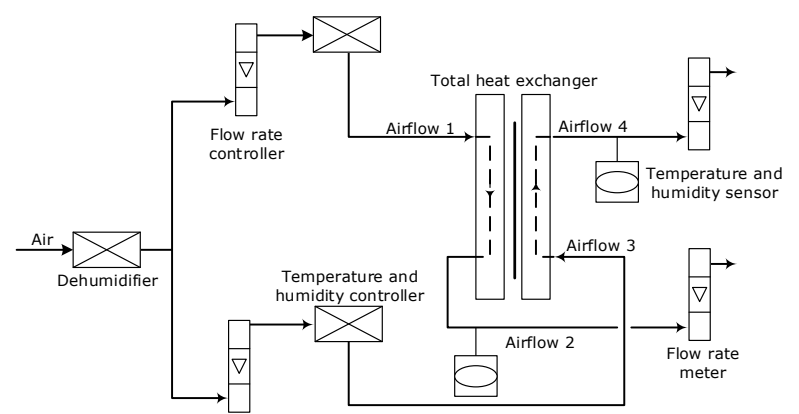

Fig. 2. Test system for efficiency analysis of total-heat recovery. Reproduced from [28].

In the case of very low outdoor temperatures and an efficient heat recovery system, the condensation of moist exhaust air and freezing of a condensate may occur. This can significantly reduce the heat transfer and air flow rate in the heat exchanger. The pre-heating of outdoor air is typically used to avoid condensation and freezing in ventilation systems. However, pre-heating significantly reduces potential energy savings. In their research, Kragh et al. [29] present a cross-flow heat exchanger able to continuously defrost itself in cold climate conditions.

In a study by Fouih et al. [30], the energy performance of heat recovery ventilation, humidity controlled ventilation and mechanical exhaust ventilation is compared for different low-energy buildings in French climatic conditions. The results of this study clearly represent that the energy performance of different ventilation systems changes greatly depending on the type of low-energy building (office or residential). For example, it was concluded that because of the short occupancy time, and high heat gains, heat recovery is less efficient in office buildings in comparison with other ventilation solutions.

\subsection{Demand controlled ventilation}

The energy consumption in a building does not often decrease after the installation of a heat recovery system [31]. This can happen if the ventilation system operates continuously even though there is no need for any air exchange; the energy consumption for the heating of inflowing air is then unjustified. To avoid this problem, demand controlled ventilation can be installed. This is a ventilation system which operates according to the actual need for fresh air.

Principal scheme of the demand controlled ventilation system is presented in Fig. 3. A demand controlled ventilation system operates systematically, or with variable power. Demand controlled ventilation can be regulated in many ways:

- Scheduled ventilation - this regulation mechanism is applied in buildings and rooms which have predictable loads. For instance, scheduled ventilation can be used in office buildings which have previously defined working hours;

- Ventilation with motion sensors - this regulation mechanism is used in rooms where the amount of people does not change over time as motion sensors can only determine whether-or-not at least one person is in a particular space. Motion sensors can be used together with scheduled ventilation to verify the programmed ventilation schedule;

- $\mathrm{CO}_{2}$ sensors - using $\mathrm{CO}_{2}$ sensors for regulating ventilation demand is energy efficient because $\mathrm{CO}_{2}$ sensors give the possibility to calculate the exact amount of fresh air needed. This ventilation regulation mechanism can be used in almost every building (except buildings where the main pollutant is not $\mathrm{CO}_{2}$ ) [33] [34].

- Demand controlled ventilation can also be joined with a building's alarm system or lighting system. If the alarm system is turned off, or the lighting system is turned on, the ventilation system is turned on.

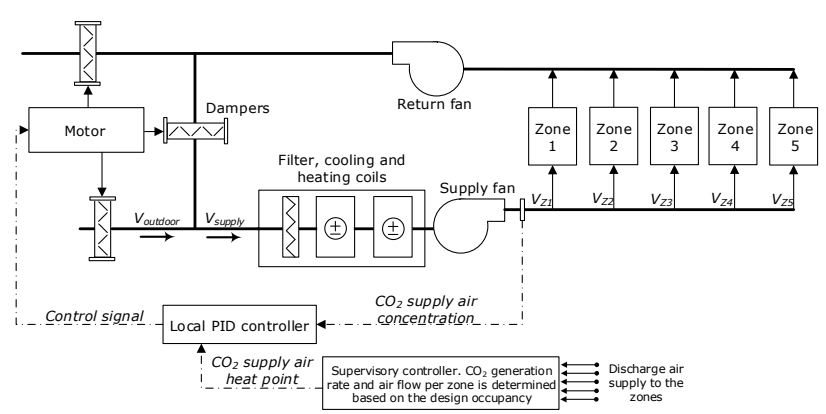

Fig. 3. Typical demand controlled ventilation system. Reproduced from [32].

Several studies on different control scenarios for demand controlled ventilation have been completed. These research papers have mainly been focused on simplifying the ventilation strategy so that it could be introduced in a wider spectrum of buildings [32;35-37]. Since demand controlled ventilation systems are more expensive than regular mechanical ventilation systems, research has been completed on how to implement ventilation strategies for ventilation systems with constant airflow [38]. Part of the research includes measuring occupancy levels of dwellings because it is an important parameter for the determination of energy consumption, efficiency, and indoor air quality. The highly varying occupancy level in dwellings creates the potential for demand controlled ventilation systems. The thermal 
performance of $\mathrm{CO}_{2}$-demand controlled ventilation systems with integrated heat recovery was tested by Fan et al. [39].

By the application of the individual control strategy to the separate rooms or even workspaces it is possible to satisfy more individuals in the comparison with the conventionally organized control for the whole building [40]. However, demand controlled ventilation system can decrease the quality of indoor air and the microenvironment.

\subsection{Geothermal for air pre-heating (earth-to-air)}

An earth-to-air system consists of air tunnel(s) buried beneath the ground, which connect outside air with inside air. When the fresh outdoor air is drawn through the tunnel, heat exchange between air and soil occurs, thus air is cooled in summer and heated in winter [41]. There are two major earth-to-air system types: open-loop where the outside air is used to ventilate the house, and closed-loop where the air from the building is recirculated through the earth tunnel (see Fig. 4). The former has proven to be more suitable in cases where the latter cannot provide sufficient amounts of fresh air [41]. For air pre-heating, closed-loop systems can be used only in cases when indoor air temperature is lower than ground temperature. The most probable application of closed earth-to-air systems will be related to keeping indoor temperature above the freezing point during non-occupancy periods and air-cooling.

When an earth-to-air system is considered, an investigation of the site's properties is vitally important. Brake [42] concluded that soil thermal conductivity is of great importance and can increase energy savings by $80 \%$. However, the possible impact for properties like density and specific heat is half of that. The importance of determining the ground thermal properties has led to the development of various methods [43;44], like the thermal response test [45] for conductivity measurements. Thermal insulation has strong effect on earth-to-air heat exchanger system's operation efficiency [46].

The study by Brake [42] in the Netherlands and a study by Zhao [47] in Canada suggests that an earth-to-air system can achieve a temperature difference of $18^{\circ} \mathrm{C}$ in winter (ambient air temperature $-12^{\circ} \mathrm{C}$ in the study by Brake [42] and $-4^{\circ} \mathrm{C}$ in the study by Zhao [47]) and $15^{\circ} \mathrm{C}$ in summer (the ambient air temperature is $31^{\circ} \mathrm{C}$ in both cases). For this type of system to work, the suggested minimal temperature difference between the soil and air is $10^{\circ} \mathrm{C}$ [48].
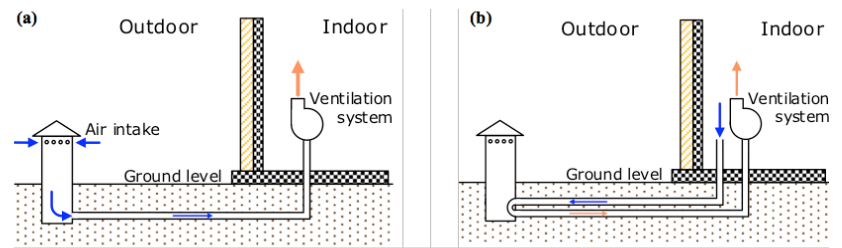

Fig. 4. Earth-to-air heat exchangers: (a) open-loop mode and (b) closed-loop mode. Reproduced from [41].

Simulations have indicated that in most cases, reducing the piping size by half can increase the temperature difference by $3^{\circ} \mathrm{C}$ in summer, and even more in winter conditions. However, smaller diameters increase pressure loss; therefore, it is recommended to use multiple smaller diameter pipes. The same applies to the length - although longer pipes reduce outlet temperature fluctuations and increase the temperature difference, every added meter above the length of $50 \mathrm{~m}$ will decrease the impact. This suggests that the use of several shorter pipes is a better solution [42]. In the study by Bansal et.al. [49] an earth-toair heat exchanger is simulated for air-heating in Indian winter conditions with different flow velocities, and pipe materials (steel and PVC). It was concluded that the difference in the performance between the materials is insignificant, and the cheapest option is the most suitable. A simulation model of the thermal performance of an earth-air heat exchanger for pre-heating and cooling of supply air, taking into account dynamic variations of climatic, load, and soil conditions was developed by Gan [50].

\subsection{Phase change materials in construction}

When phase change materials (PCM) are used for heat storage during daytime and release at nighttime, it is called nocturnal ventilation [51]. PCM properties make them useful for both cooling and heating.

Some of the ways to use PCM in heating systems is to integrate them in construction materials and elements [52]; for example, in the study by Alwadhi and Alqallaf [53] it was concluded that the integration of PCM in the building roof allows for a reduction in the heat transfer by 39\%. PCM flexibility makes it easy to use in existing buildings by placing them in double skin facades (DSF) or trombe walls [54] where sensible heat storage using water tanks would not fit. In a numerical study, Sayyar et al. investigated the integration on nano PCM into building envelope products. The results of this study indicated a reduction of $79 \%$ in energy demand within a comfortable indoor temperature level [55].

PCM are typically used in ventilation systems in two different ways:

- $\quad$ PCM are built into the floor, walls, and ceiling of a room to increase the thermal inertia of the building. This is coupled with night cooling in the summer period to decrease the buildings cooling load and energy consumption [56];

- PCM storage is built into the ventilation system. This is also used for night cooling when mechanical ventilation is turned on during the night, and airflow is directed through a container filled with PCM spheres, granules, or differently shaped particles $[15$; 56-59].

Some of the advantages of PCM are a smaller temperature swing between day and night temperatures, a smaller size, and a lower weight per unit of storage capacity with higher energy density [60]. For a long time, a drawback to using PCM was the possibility of leakage in its liquid state. Another disadvantage of PCM is the low thermal conductivity which makes the melting and solidification process last longer. To speed up these processes, different approaches have been studied: the use of finned tubes [61] [62] [63], metal matrix [64], [65] using bubble agitation [66], and adding conductive particles. Pielichowska and Pielichowski provided the latest review on state-of-the-art of PCMs for thermal energy storage applications [67].

There are very few scientific articles on using PCM in cold climates for reducing a building's energy consumption or using PCM in ventilation systems. Research by Gracia et al. [54] on a ventilated facade with encapsulated PCM during the winter period has been carried out in Mediterranean winter conditions with mild outdoor temperatures. The study concluded that this solution significantly reduces the electricity consumption of the 
HVAC systems - $19 \%$ to $26 \%$ under severe winter conditions.

\subsection{Passive use of solar energy}

The term passive use of solar energy includes methods, materials, and technologies applied in the construction of building elements for the admission, absorption, storage, and use of solar energy [68]. In this case, no solar collectors, pumps, fans, or other active components are involved [7]. Passive solar heating technologies are based on solarinduced convection of air [69] or vapor [70]. Ryan and Burek [69] have carried out an experimental study of buoyancy-driven convection in an asymmetrically-heated channel like in a passive solar air-heating technologies. The results are displayed in correlation with the air flow and efficiency against heat input, and channel . They found that thermal efficiency is a function of the heat input and the system height, but not the depth. However, the mass flow is dependent on all three parameters.

There are different configurations of passive solar heating systems. One of the most common solar passive heating techniques is a trombe wall [71]. A trombe wall heats the room air by recirculating it through a thermal storage wall that is heated by solar radiation through a transparent outer wall cover [72]. Numerous studies have been carried out regarding passive heating trombe walls: an air-flow simulation by Hami et al. [73], optimization simulation for the Mediterranean region by Jaber and Ajib [74], experimental evaluation in a subtropical location by Krüger et al. [75], as well as research on trombe walls incorporating phase change materials for temperate and hot climates by Fiorito [76].

Quesada et al. [77] have completed a review of theoretical and experimental studies, pertaining to development and feasibility studies on opaque solar facades, including passive technologies such as trombe walls and solar chimneys. A solar chimney is similar to a trombe wall, the difference being that a solar chimney is a shaft that allows indoor and outdoor air exchange. Solar chimneys have been quite widely studied for natural ventilation applications, but very little for inlet air heating [71]. In a study by Haghighi and Maerefat [71], solar chimney capability for ventilation heating during winter days is modeled (see Fig. 5). The interconnections between indoor climate, design parameters, and environmental conditions are analyzed in this study.
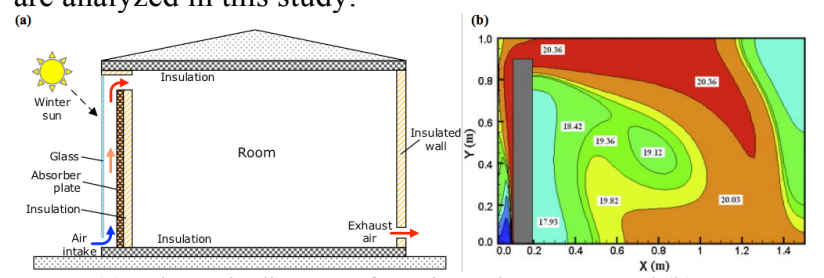

Fig. 5. (a) Schematic diagram of passive solar system and (b) temperature distribution map (total incident solar radiation on south facing surface $-300 \mathrm{~W} / \mathrm{m}^{2}$, ambient temperature $-10.0^{\circ} \mathrm{C}$ ). Reproduced from (A.P. Haghighi, 2013)

Double-skin facades are becoming increasingly popular [78], particularly for use in office buildings [79]. The idea of a double skin facade is based on the creation of two building envelopes with an intermediate cavity. The cavity in the double-skin facade can be ventilated mechanically or naturally. The naturally ventilated facade is a passive solar system. Quesada et al. [79] have completed a review of transparent and translucent solar facade technical and experimental studies, feasibility studies and application examples, including passive, naturally ventilated facades. In an experimental study on an opaque ventilated facade by López et al. [80] it was concluded that the performance of the ventilated facade depends on the wind speed and direction, and solar radiation as well as the geometry and location of the building. Similar conclusions were made in an experimental study by Gracia et al. [78]. A double skin facade with integrated PCM could almost replace the ventilation system during the mild Spanish winter [78]. Zhou and Chen [81] pointed out that deep preliminary analysis is required before application of double skin facades. However, there are few methods available to analyze the complex processes involved. Further research in this field is needed.

A passive ventilation air heating configuration, other than the ones located in a building's exterior walls, can be situated in a ventilated double window. This technology can be implemented in new, as well as existing buildings [82]. The air intake takes place through the cavity between the window glazings (see Fig. 6 a). On the one hand, the heat lost from the inside through the window returns back to the room by the incoming air flow, the double window serves as a recovery system; on the other hand, solar radiation warms the window components and the incoming air [83]. An experimental study, modeling, and simulation analysis [8284] has been carried out by Carlos et al. The effect of solar collection and recuperation functions was analyzed. The authors concluded that a ventilated double window is the most advantageous in a system facing south; however it is suitable for any other facade orientation because heat recovery is the dominant function of a ventilated double window. By changing the window orientation from south to north, the heat gain decreases by $22 \%$ in mild Portuguese winter conditions, while decreasing $6 \%$ in the case of Munich. The double window application can reduce heat loss due to ventilation by $22 \%$ in Portugal and $24 \%$ in Munich when facing north, while by $28 \%$ and $26 \%$ respectively when facing south [83].

Based on data monitoring over a two-year period, Cordeau and Barrington [85] evaluated the performance of solar air pre-heaters installed close to Montreal, Canada. Unglazed air pre-heaters with a corrugated black metal surface were studied (see Fig. 6 b). Natural gas heaters were used as auxiliary heaters in the barns. The main conclusions of this study present a very strong effect of wind on the thermal performance of solar air pre-heaters. In the case of a wind velocity below $2 \mathrm{~m} / \mathrm{s}$, an average of $65 \%$ efficiency was observed. The efficiency dropped below $25 \%$ for wind velocity exceeding $7 \mathrm{~m} / \mathrm{s}$. During the heating season $\$ 14.80$ CAD. $/ \mathrm{m}^{2}$ were recovered by the solar air pre-heaters, which is equal to $4.7 \%$ of the annual return on investments [85].
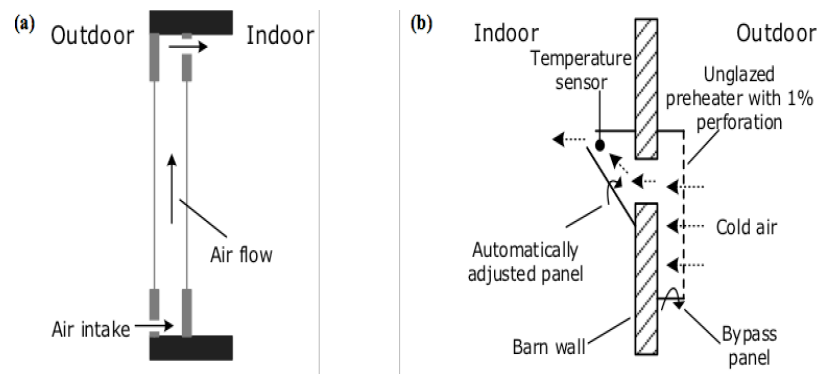

Fig. 6. Configurations of a (a) ventilated double window (reproduced from (J.S. Carlos, Heat recovery versus solar collection in a ventilated double window, 2012)) and (b) unglazed perforated solar air pre-heater (reproduced form (S. Cordeau, 2011)) 


\subsection{Closed buildings}

The more outdoor air is used for ventilation, the more auxiliary energy has to be used for warming this air during the heating season. This occurs regardless of the ventilation system and its energy efficiency. From an energy savings point of view, the most energy efficient solution is to not take any outdoor air, but to only use indoor air and keep it in the quality needed for the inhabitants. This could be done in two ways - all the necessary air for compensating the effluent ventilation air is stored in the building, or the air is regenerated $\left(\mathrm{CO}_{2}\right.$, VOC, odors and other contaminants are continuously removed from the indoor air).

To store all the necessary fresh air for the heating season in the building, large pressurized vessels would be needed. To ensure appropriate quality indoor air, $15 \mathrm{~m}^{3}$ of fresh outdoor air per hour is needed per person [86]. Commercially available pressurized vessels can store air at pressures up to $30000 \mathrm{kPa}$, or 4350 psi [87]. Based on Boyle's law [88], under this pressure, a $1 \mathrm{~m}^{3}$ large vessel would hold $260 \mathrm{~m}^{3}$ of outdoor air at the normal pressure (101.325 kPa or $14.7 \mathrm{psi})$. This is enough air to ensure one person with appropriate air quality for more than 17 hours. If the heating season lasts for approximately 200 days, and one person spends roughly 12 hours in a building, a vessel of $138 \mathrm{~m}^{3}$ would be necessary to ensure all the required air. This vessel could be charged with fresh air during the summer. For the charging, renewable energy sources could be used and part of the energy could be recovered during the discharge process. In this way, a solution for energy storing, which comes to be a challenge with inconsistent energy sources such as wind power or solar radiation, is provided. There has been no research done in this field of building ventilation yet. The idea, and the above mentioned calculations, are a proposition of the authors of this paper. Air temperature changes after compression and expansion cycles could be used for heating and cooling purposes.

The second possibility for making the building independent from outdoor air intake is to regenerate the air required for breathing. This has already been implemented in enclosed spaces such as international space stations. The main contaminant in enclosed human populated spaces is $\mathrm{CO}_{2}$, which builds up over time. To remove $\mathrm{CO}_{2}$ from indoor air, it is possible to use a hollow fiber contained hydrogel-CA membrane contractor [89]. Carbon dioxide can also be adsorbed by using amino functionalized silica aerogels at a low pressure [90]. Different sorbents were used in a study completed by Mattox et al. [91] to compare their potential to remove carbon dioxide from the space-habitat. Whole life support systems that also include $\mathrm{CO}_{2}$ removal and $\mathrm{O}_{2}$ generation have been studied [92;93]. These research works seek to find ways of ensuring good indoor air quality, but the research lacks information on the energy efficiency of $\mathrm{CO}_{2}$ removal. In a building, the energy is used for warming up the incoming outdoor air, but energy is also used in the $\mathrm{CO}_{2}$ removal system. It is not clear how much energy is consumed to remove $\mathrm{CO}_{2}$ from enclosed spaces. Research still has to be done to compare energy consumption, and the energy efficiency of warming the incoming outdoor air and removing $\mathrm{CO}_{2}$ from the indoor air.

\section{Use of Renewable Energy Sources for Heating Ventilation Air}

\subsection{Solar energy}

Solar air heaters (SAHs) are the simplest way to transform solar energy into heat [94]. The most typical solar air heater is a flat plate solar collector with specific solutions for proper heat exchange between the absorber plate and passing air. Solar air heaters can be implemented in two ways - by supplying the heated air directly to a consumer, or by involving an air-to-liquid heat exchanger. The second solution allows combining solar air heaters with a wide range of conventional and innovative heat supply technologies; however, in this study only the first one is reviewed.

The main application of solar air heaters is related with space heating, drying [95] and curing [94;96]. The classification of solar air heaters by function of the materials and technologies used are given by Oztop et al. [96].

The main advantages of solar air heaters are:

- A cheap and simple design, simple maintenance [94;96;97];

- Protection from freezing or boiling [11;68;96;97];

- Non-corrosive heat carrier [68];

- Heat carrier is free of charge [68];

- High stratification in case of pebble bed storage [68].

The disadvantages are:

- Air handling equipment needs more space [68];

- $\quad$ It is difficult to detect leakages [68];

- Higher parasitic electricity consumption as compared to liquid systems [68];

- Problematic integration of solar air conditioning [68];

- Low performance of air as a heat carrier $[11 ; 68 ; 94 ; 96]$.

In a study by Kalogirou [68], a detailed review on solar thermal collectors, performance analysis, and applications is presented. A part of this review is focused on the solar technologies for air heating. The principal scheme of a solar air heater with integrated packed (pebble) bed storage is shown in Fig. 7. The use of controllable air dampers allows for smart regulation performance as a function of the actual solar gain and heating load. The auxiliary source is used to reach the required air temperature, and it can work in parallel with solar air heaters or pebble bed storage. The mode with a load fully covered by the auxiliary source and solar collectors working in bypass is also possible. To get a fixed output temperature from a collector, regulation of the flow rate is required. However, this reduces the performance of the collector when the flow rate is low $[68 ; 95]$. A heat transfer mechanism and energy efficiency of artificially roughened solar air heaters are presented in a different review completed by Patil et al. [98].

The design of solar air heaters and heating systems requires deep knowledge in thermodynamics, materials, optics etc. One of the most powerful optimization tools for different tasks is Computational Fluid Dynamics (CFD). Yadav and Bhagoria (A. S. Yadav, 2013) did a review on CFD applications for designing solar air heaters, concluding that CFD is a powerful tool for the prediction of the behavior and performance of solar air heaters. However, similar to any other optimization method, the CFD approach has 
several limitations and challenges - in particular the selection of the proper turbulence model (A. S. Yadav, 2013).

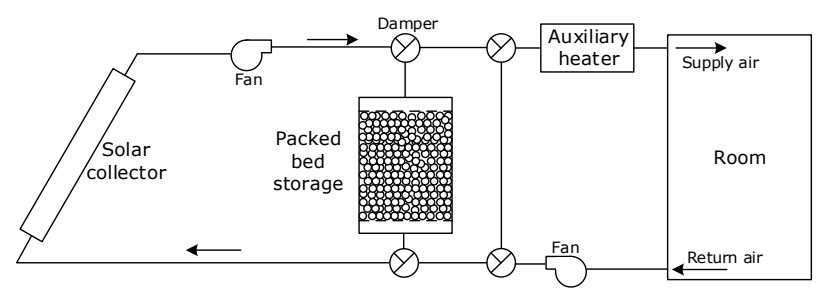

Fig. 7. Schematic of simple solar air heater with pebble bed storage. Reproduced from [99].

$\mathrm{Hu}$ et al. [97] used CFD software for the simulation and analysis of a solar air collector with internal baffles. The number of baffles, the thickness of the air gap, the number of glass covers, and environmental conditions were used as independent variables for this study. The application of internal baffles makes the flow more turbulent, and allows for the extension of the air retention time, and has an overall positive effect on efficiency. However, air trapping in some regions results in a temperature rise and an increase of heat loss. In this specific case, the optimum solution was to have three internal baffles and an air flow rate in the range of 20 $40 \mathrm{~m}^{3} /\left(\mathrm{m}^{2} \mathrm{~h}\right)$ [97]. In a study by Yadav et al. [100] twodimensional CFD model was used to investigate the thermal and hydraulic performance of a solar-air-heater with differently configured absorber plate. Detailed results about the average heat transfer and fluid friction for a system are presented. The optimum value of the thermo-hydraulic performance parameter was found and discussed.

Computational fluid dynamics is not the only advanced method to be used for design, analysis, and optimization of complex processes and systems. There are numerous modern methods, tools and techniques (e.g. artificial neural networks) available for studies related to renewable energy systems, including solar thermal systems [101].

\subsection{Phase change materials for solar-to-air applications}

Solar collectors require a heat storage system to store the thermal energy produced by the collectors [102]. The use of phase change materials has become very attractive for this application. The main advantage of PCM, as a technology for heat accumulation, is the possibility to store a large amount of energy in the form of latent heat. The heat energy is stored in a constant temperature which corresponds to the phase change temperature of the PCM [103]. The proper selection of the phase change temperature will avoid the overheating of air during high solar radiation periods, and extend the duration of the utilization of the solar energy [95].

Specifically for air-heating applications, PCM can be filled in small size containers (typically spherical or flatplate) and packed in heat storage units. This solution has a very high contact surface-to-volume ratio while still being simple [95]. Saman et al. [104] presented a mathematical analysis of the transient thermal behavior in a PCM storage unit. For model validation, an experimental air-heating solar system is used. Thermal storage is made using several parallel layers of PCM with a melting temperature of $29^{\circ} \mathrm{C}$. A similar study by Charvat et al. [105] has recently been published. An experimental solar heat storage unit containing 100 aluminum panels filled with a paraffin-based
PCM (melting at $\sim 41^{\circ} \mathrm{C}$ ) was tested and described numerically. Based on experimental and simulation results, it was concluded that PCM based thermal storage has the potential to be used in air-based heating systems. However, constant outlet air temperature can be achieved only by changing the air flow rate in the function of solar radiation and outdoor temperature [105].

Esakkimuthu et al. [95] present a study on the use of PCM in solar drying applications. Based on the drying requirements, an inorganic salt $\mathrm{HS} 58$ with a melting/freezing temperature $58 / 57^{\circ} \mathrm{C}$ was used. PCM was filled in spherical containers; the packed bed storage was used for the experimental setup. In this case, the use of PCM permitted the extension of the drying process, higher collector efficiency, and lower parasitic energy consumption.

It should also be mentioned that in the case of ventilation air, the required supply temperature is typically much lower in comparison to the drying and industrial processes. This forms better conditions for the effective use of solar air heating technologies and the application of PCM heat storage.

\subsection{Photovoltaic thermal collectors}

SAHs could also be integrated with photovoltaic (PV) units to produce both thermal and electrical energy in one system. These types of systems are called photovoltaic thermal $(\mathrm{PV} / \mathrm{T})$ collectors. The main advantage of this technology is related to the negative effect of temperature on the efficiency of PV units. In the PV/T unit, excess heat is transferred to a heat carrier providing a cooling effect to the photovoltaic part, while increasing the overall efficiency of the system. The production of electricity and heat in one unit takes less space in comparison with separate production.

There have been three reviews on $\mathrm{PV} / \mathrm{T}$ technologies published recently providing a deep background on the theoretical aspects, performance analysis, and practical applications of PV/T technology [106-108]. For PV/T technologies, a higher market potential is expected in comparison with separate PV and solar thermal technologies [107], with the residential sector as a main customer [108]. Chow et al. [106] forecast that $\mathrm{PV} / \mathrm{T}$ technologies will become competitive with conventional electrical energy more rapidly than single PV. However, there is still a lack of long-term testing of $\mathrm{PV} / \mathrm{T}$ units in real applications, under real climatic conditions [106;107].

Air is widely used in PV/T units as a heat carrier because of its availability and technically simple design of the units [106]. Therefore, air-based PV/T units can be widely used for ventilation purposes. However, as heat carrier air has low thermal conductivity and specific heat capacity, air-based $\mathrm{PV} / \mathrm{T}$ systems typically have lower electrical and overall efficiency in comparison with other types of systems (water, refrigerant or heat-pipe based solutions). Assoa et al. [109] studied experimental a $\mathrm{PV} / \mathrm{T}$ air collector concluding that forced ventilation of the unit can provide sufficient air preheating, but is less significant for electrical performance optimization. Therefore, there is a low potential for technological improvements of air-based PV/T units [107].

$\mathrm{PV} / \mathrm{T}$ units can be integrated with phase change materials in a united system. A study done by Assoa and Menezo [110] presents such a type of integrated system used for ventilation purposes. Results showed that in winter conditions the proposed system can significantly improve the indoor thermal comfort level in a passive building. 
Night-time sky radiative cooling can be used in summer conditions to increase the thermal comfort of the building.

\subsection{Heat pumps}

In big commercial and public buildings, air exchange is typically controlled by heating, ventilation, and air conditioning (HVAC) systems. With increasing building air tightness, the use of HVAC systems has also become more attractive in smaller scale buildings. In an HVAC system, the incoming outside air can be heated in a pre-heater and subsequently mixed with a part of the exhaust air. The mix is then sent through a heating/cooling coil to suit the exact building requirements. In an HVAC system, a heat pump could be used as a pre-heater. In addition, a heat pump can provide pre-cooling and dehumidification during the summer period [111-113].

Different heat pumps can be retrofitted in different kinds of HVAC systems resulting in notable primary energy savings and increased comfort. It is possible to implement heat pump systems solely for ventilation air heating and/or cooling or to simultaneously incorporate it for ventilation heating/cooling and hot water supply and/or space heating. The demand for multifunctional heat pump systems has increased significantly [114-116].

Heat pumps use well-known principles of refrigeration systems, moving energy from a lower temperature source to a higher temperature sink [112;116]. Heat pumps can be equipped with a refrigerant flow reversing valve that can change the roles of the evaporator and condenser, allowing it to adjust to the necessary climatic conditions [112].

Heat pumps are driven using electrical energy, but the economic benefit is obtained because a heat pump typically requires 1 part of the electricity to turn 2 parts of free environmental heat (usually a low potential heat) into 3 parts of useful heat. This also results in an environmental benefit as the heat pump creates less carbon dioxide than fully electric, oil, or gas heat production systems [116]. There are different heat sources which are useful for heat pumps, but the most common for ventilation air-heating applications are exhaust air, ground (or water), outside air, and to some extent sewage. Moreover, a mixing of heat sources can offer attractive solutions as well.

\section{Exhaust air}

Compared to the more common outdoor air heat pumps, exhaust air heat pumps are particularly suitable for heating the ventilation air in Northern countries because these heat pumps tend to reach higher efficiency for this application. This is due to the fact that in a cold climate, the outdoor air temperatures are low, while the exhaust air temperatures are very favorable. In comparison with the ground source heat pumps, the exhaust air-based systems are much less complicated [117].

An article by Calay and Wang [118] proposes a hybrid ventilation system that uses waste heat from the exhaust air to pre-heat the supply air. The experimental study is carried out for a system using a rotary heat exchanger along with a reverse cycle heat pump (see Fig. 8). In the experimental system, the exhaust air heat pump saves between $64 \%$ and $73 \%$ of heat energy in comparison to conventional solutions [118].

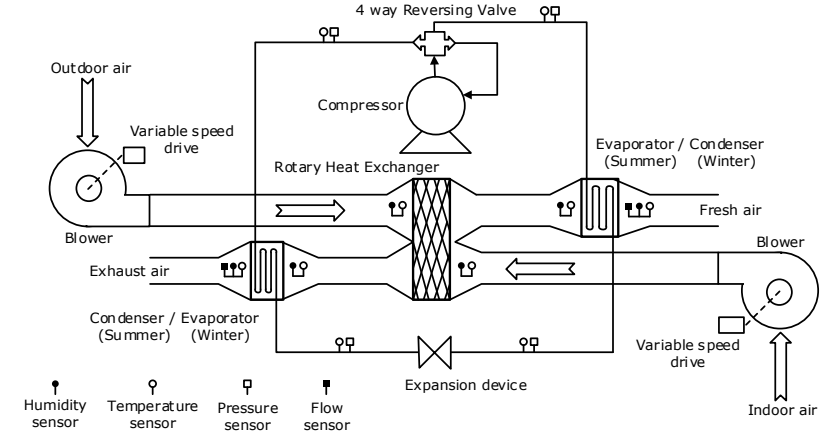

Fig. 8. Schematic layout of the proposed heat pump system using exhaust air. Reproduced from [118].

When there is a risk of supply air, which could be contaminated by exhaust air (e.g. hospitals and the processing industry), or the supply and exhaust air flows are located far from each other, run-around coil heat recovery is usually implemented. In a study by Wallin et al. [2], heat pumps were introduced to be used to increase the energy efficiency of the ventilation system with run-around coil heat recovery. A numerical study is performed to compare conventional three-stage on/off controlled heat pump and a variable capacity heat pump integrated into the system. The study was situated in Stockholm. By retrofitting a three stage-heat pump to the run-around coil heat recovery system, the annual heat recovery rate can be increased from $47 \%$ to $65 \%$ and heat pump can cover $81 \%$ of the total heat demand in the system. In comparison, a variable capacity heat pump can increase heat recovery from $47 \%$ to $66 \%$ by retrofitting a three stage-heat pump and variable capacity heat pump into the ventilation system with a run-around coil heat recovery. In this situation, heat recovery improved from $47 \%$ to $65 \%$ and $66 \%$ respectively. A variable speed heat pump was able to cover $81 \%$ of the annual heat demand and a three-stage pump - 77\%. However, a heat recovery system with a three-stage pump represented a slightly better economic performance [2].

\section{Sewage}

Systems which use waste water as a source have been studied by Zwang et al. [119], Zhuang et al. [120] and Xuehui and De-xing [121]. Large sewage systems provide substantial quantities of a stable heat source; therefore, it is more popular in urban areas. The temperature of the sewage is usually in the range of $10^{\circ} \mathrm{C}$ to $20^{\circ} \mathrm{C}$ in summer, and rarely below $10^{\circ} \mathrm{C}$ in winter, making it suitable for heat recovery systems [122].

Systems with heat recovery from sewage in combination with solar collectors have been studied [123;124]. Davidsson et al. [123] proposed systems with mechanical, or alternatively - natural ventilation, where sewage tanks are used to heat fresh air (see Fig. 9). A comparison of a mechanical and a hybrid system is made. The results from this study indicate that the hybrid system would lead to higher energy savings [123].

Solutions for public shower facilities (schools and barracks) have been studied by Liu et al. [124]. The authors concluded that the annual operating cost of the heat recovery system for showers is almost half of the traditional solaronly systems, and more than three times lower than for the traditional fossil fuel boilers. In addition, for a solar system to provide enough energy, it would require a large area and have a high installation cost, while some fossil fuel boilers would create serious pollution problems. The use of another 
heat source in combination with waste water could provide better results than using only a single source. A combination of grey water and air as heat sources for space-heating and/or hot water supply has been investigated by Liu et al. [125].
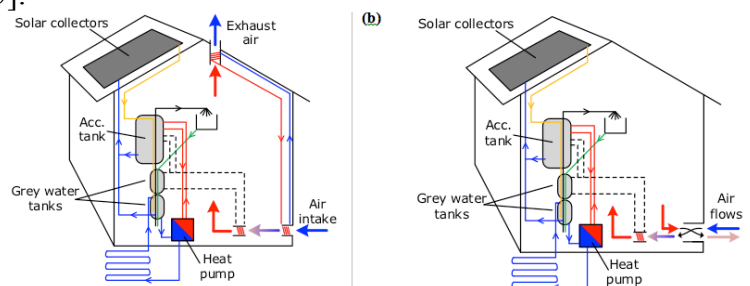

Fig. 9. A sewage heat recovery systems with (a) natural and (b) mechanical ventilation studied by Davidsson et al. Reproduced from [123].

The main obstacle for direct systems, where heat is recovered from sewage, is to clean the sewage before it enters the heat exchanger. Preparation includes the removal of fats, detergents etc. that could create build-up on the surfaces of the heat exchanger. On-site water sewage treatment systems can be utilized, which favor the idea of an independent passive house [123]. Other researchers suggest using coil type heat exchangers that have a lower level of efficiency, but are easier to maintain. Consequently, they are more suitable for sewage application [125].

\section{Ground (water)}

The common belief that special geological conditions like hot springs are needed for the application of ground heat pumps is incorrect. Below the frost line, the ground and water temperature is fairly constant, providing a source of heat during winter and cooling during summer. Geothermal energy based systems can provide significant economic and environmental benefits while maintaining a high comfort level and low operational costs [116].

Heat pump systems combining multiple heat sources, and heat pump systems with multiple heating applications, often look more attractive than creating a single ventilation air-heating heat pump unit. A study by Jung et al. [114] states that previous studies were more focused on single staged and cascade heat pump water heaters, and not multifunctional air and water heating units. Thus, an experimental optimization study of a cascade multifunctional heat pump for air heating and hot water preparation was carried out. A comparison with a single stage multifunctional heat pump was done. The system was optimized by changing the operational parameters. The results show that the cascade multifunctional heat pump provides a more stable operation and higher output in comparison with a single-stage pump [114].

Busato et al. [126] discuss a case study of a new wellinsulated school building in Northern Italy with a multisource heat-pump system providing heat for space heating and ventilation. The exhaust air and ground is be used as a low potential heat source for the ventilation heat pumps. Ground and solar collectors provide heat for the space heating heat pumps. The functioning parameters of the system were monitored monthly for a two-year period and a comprehensive system performance evaluation was performed. It was concluded that the integration of different heat sources increases thermal performance of the heat pumps significantly. The key factor of that is a use of solar thermal energy as a heat source for the heat pumps. More than half $(52.2 \%)$ of the heat energy needed for ventilation was produced by the heat pumps, and $40.7 \%$ was recovered by a static recuperator leaving only $7.1 \%$ to be covered by the auxiliary boiler [126].

Ploskić and Holmberg [127] investigated the possibility of using new low temperature air-heating units combined with existing space heating radiators in Swedish winter conditions. The idea of this study was to reach low temperature operation conditions suitable for heat pumps in existing radiator based space heating systems. The results of this study showed that proposed air-heating units are able to heat outdoor air by more than $33^{\circ} \mathrm{C}$ and provide the level of comfort needed by using $40^{\circ} \mathrm{C}$ water. Moreover, the authors clearly highlight the advantages of locally organized air preheating in comparison with the direct intake of outdoor air [127].

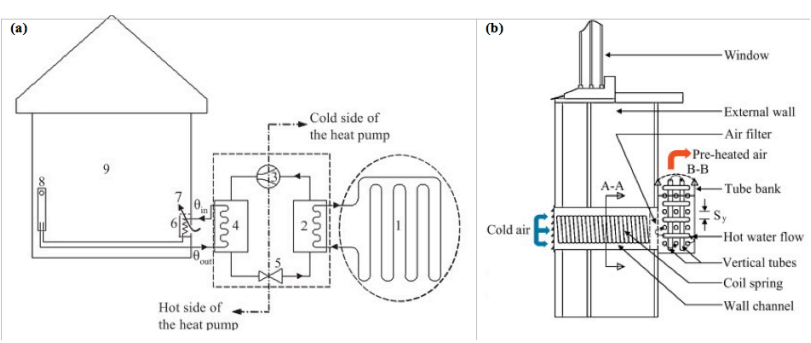

Fig. 10. (a) Heat pump based heating system with radiators used for outdoor air pre-heating $\left(\Theta_{\text {in- }}\right.$ supply and $\Theta_{\text {out- }}$ return water temperature; 1- heat collector, 2- evaporator, 3- compressor, 4- condenser, 5expansion valve, 6- proposed air-heater, 7- air supply, 8- radiator and 9-

Another study by Rad et al. [128] discusses the viability of a solar assisted ground source heat pump (SAGSHP) system for forced air and radiant floor heating, and hot water heating in cold climate conditions. For the study, a dynamic simulation model for the yearly performance of a conventional ground source heat pump system as well as SAGSHP system was built. In situ data were evaluated against the simulation output. It concluded that SAGSHP systems would be feasible for satisfying the heat demand of a building in cold climate. The economic benefit is dependent on the particular climatic conditions, system installation costs, and the interest rate [128].

As the heat pump heating units can only reduce, but not replace the use of electricity, it is desirable to implement a renewable energy source for the production of the electricity. Li et al. [129] propose a wind power and solar thermal multisource heat pump system for heating, hot water preparation and cooling in residential buildings. The system includes a water source heat pump for space heating and cooling and an outside air source heat pump for hot water preparation. The electricity produced by the wind turbine is used for the heat pumps. The heat output from solar collectors is used for the pre-heating of domestic hot water, and as a heat source for the water heat pump. The system is modeled for Beijing weather conditions, and it has been discovered that $7.6 \%$ of the yearly electricity demand can be covered by wind turbine, and the proposed system decreases the yearly carbon dioxide emissions by $31.3 \%$ in comparison with conventional solutions [129].

\section{Historical Changes Within the Field: A Summary}

An analysis of the quantity of scientific publications dealing with the above-mentioned building ventilation technologies 
was completed during this study. Publications included in the SCOPUS database were chosen for this analysis. Not all scientific papers on the topic in question were found during this study, but the way how the search was performed ensures that the results are comparable and can represent scientific intensity in the field. The number of works published, and the year of the publication shows the level of development and time invested researching each building ventilation technology. The results of the search are shown in Fig.11. This search of scientific papers shows the state of research in each of building ventilation technology.

An increase of published papers on heat recovery, passive solar heat utilization, and heat pumps (in ventilation applications) can be seen during the time period from 1980 till 1990. During this period, increased attention to the energy efficiency and use of renewables in ventilation systems can be observed. Earlier studies related to demand controlled ventilation and the use of geothermal heat for air pre-heating were also published during this period. Firstly, the scientific community focused more on heat recovery in ventilation. A great deal of work has been completed in recent times [18] (see Fig.18), leaving little space for improvement within conventional sensible heat recovery technologies. However, a growing demand [18] and complex optimization and introduction of composite membrane-based materials for latent heat and moisture transfer [28] raised the scientific attention given to heat recovery, and contributes to the competitiveness of this technology [130]. Furthermore, polymer material for specific application [24] is still the most popular technology included in 50 related studies during 2014, and represents more than 760 references included in the SCOPUS database since 1969. The reason for that is simple - heat recovery can be stated as a single technology with the highest energy saving potential in buildings [18].

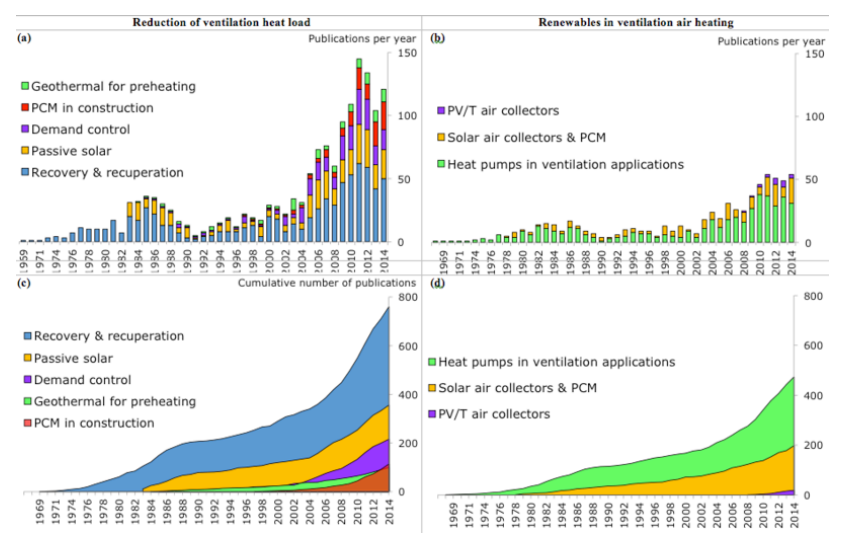

Fig. 11. Related scientific references included in the SCOPUS database and published in the fields of engineering, energy, environmental, and material sciences. Technologies and solutions for: (a) and (c) ventilation heat load reduction; (b) and (d) - use of renewables in ventilation air heating

In the 1990s, scientific intensity in this field decreased significantly. The number of studies published started to increase significantly around 2000, and has been steadily increasing ever since. A great deal of focus has been given to the passive use of solar energy, and demand control ventilation. Passive solar technologies are largely studied in mild-winter conditions [71;72;74-76]; further research of these technologies has to involve deep economic analysis, architectural aspects, and severe winter conditions as well [8;9].

Heat pumps are already recognized as efficient technology with a high environmental and economic performance $[13 ; 14]$. It is the second most discussed technology in connection with ventilation air heating (see Fig. 11). The significant advantages of heat pumps are the numerous primary heat sources, high environmental and economic performance in the case of green and cheap available electricity $[13 ; 14]$. Because of low temperature regimes, the possibility to recover heat from exhaust air and cooling options in ventilation application heat pumps has to be evaluated as a heat source option with the highest priority.

In comparison to commonly used liquids, air has poor heat transfer properties [11] which limits the application of active solar air-heating technologies. However, technically speaking air-based systems are very simple [11;94;96;108], and in the case of low temperature applications (such as ventilation air heating or pre-heating) can be widely used while providing environmental and economic benefits [68]. A combination of photovoltaic and air heating functions in a single unit provides a simple way to increase electrical and overall efficiency of PV/T's. Currently, this technology is at the R\&D stage and lacks deep economic evaluation and real life applications [106;107]. However, integration possibilities and simultaneous production of renewable electricity and heat definitely increases the potential of $\mathrm{PV} / \mathrm{T}$ 's to be used in sustainable buildings.

Due to a great deal of thermal energy being stored in the form of latent heat, and at a constant temperature, PCM is currently developing as a very intriguing technology for heating and cooling applications in the construction and energy sectors. It is a relatively young technology, in spite of this it is the third most discussed technology in this field over the last two years. The use of PCM has been successfully tested as a tool to increase the thermal capacity of buildings, while reducing swings and peaks of indoor temperature, cooling, and heating loads [15;16;56;57]. Phase change materials can be widely used to avoid or reduce the mismatch between the actual heat load and output from irregular heat sources [110]. Isothermal phase change provides a technically simple way to improve the performance of temperature sensitive technologies, like solar collectors [103]. Moreover, PCM can be easily integrated in ventilation air flows while providing a wide range of benefits [110]. Cost reduction [15], improvement of thermodynamic properties and reliability $[16 ; 17 ; 52]$, real life application, integration, testing, and optimization [16;56] are the aspects that need scientific attention in the future.

\section{Conclusions}

Energy efficiency and the utilization of renewable energy in buildings is an important way to promote sustainable development, and to reduce the environmental load of existing and future buildings [131]. High energy and environmental performance of new or renovated buildings requires a ventilation system which is able to provide the necessary amount of fresh air with a minimal consumption of fossil energy. In terms of energy ventilation, air heating takes a significant part in the building's energy balance. In the Nordic climate conditions, air heating can consume much more in comparison with cooling or electricity needs for ventilation [132]. 
This work has provided a review of the technologies and methods for the heating of ventilation air as a key aspect for high energy and environmental performance of buildings located in a cold climate. Energy efficient and sustainable ventilation should integrate three main components: a control strategy specifically developed to match the actual demand recuperation technology, be able to recover maximum heat energy from the exhaust air and technologies, and be able to convert renewable energy or waste heat into useful heat energy. To reach high results, the concept of complex integrated systems $[57 ; 106 ; 133]$ and the whole building approach $[7 ; 134]$ has to be applied, especially to the design and optimization phase. In every case, the demand of ventilation air should match the actual need of fresh air. A properly developed control strategy for existing and new units is the key for energy efficient ventilation and the proper use of renewables.

Low temperature regimes in ventilation applications are very suitable for low potential heat sources, making heat pumps, solar thermal technologies (both passive and active), and waste heat recovery more efficient and feasible.
Moreover, heat pumps, earth-to-air systems and solar air heaters (during night time) can be used for ventilation air cooling during summer.

In general, all of the technologies included in this work (besides closed buildings) have been classified by the scientific community as efficient, scientifically popular, and with a high potential to increase the energy efficiency and sustainability of buildings. However, only a few of them (e.g. heat recovery or heat pumps) are currently available on the market and can be easily found in residential or commercial buildings these days. Economic performance is typically not the point of interest for scientists, and it is very rarely analyzed in scientific studies. However, the main aspect defining development after the $R \& D$ stage is commercial potential.

\section{Acknowledgements}

Support for this work was provided by the Riga Technical University through the Scientific Research Project Competition for Young Researchers No. ZP-2013/13.

\section{References}

[1] Dimitroulopoulou C. Ventilation in European dwellings: A review. Building and Environment 2012;47:109-25.

[2] Wallin J, Madani H, Claesson J. Run-around coil ventilation heat recovery system: A comparative study between different system configurations. Applied Energy 2012;90(1):258-65.

[3] The European Parliament and the Council of the European Union. Directive 2010/31/EU of the European Parliament and of the Council of 19 May 2010 on the energy performance of buildings. Official Journal of the European Union 2010;53.

[4] Latvijas Republikas Ministru Kabinets. Noteikumi Nr.383 Noteikumi par ēku energosertifikāciju. Latvijas Vēstnesis 2013;138(4944).

[5] Boyle G, Everett B, Morris D, Scurlock J, Ramage J, Elliott D, et al. Renewable Energy. Power for a sustainable future, Third Edition, Oxford: Oxford University Press; 2012, p. 566.

[6] Chua KJ, Chou SK, Yang WM, Yan J. Achieving better energyefficient air conditioning: A review of technologies and strategies. Applied Energy 2013;104: 87-104.

[7] Stevanović S. Optimization of passive solar design strategies: A review. Renewable and Sustainable Energy Reviews 2013;25:177-96.

[8] Chan HY, Riffat SB, Zhu J. Review of passive solar heating and cooling technologies. Renewable and Sustainable Energy Reviews 2010;14:781-89.

[9] Saadatian O, Sopian K, Lim CH, Asim N, Sulaiman MY. Trombe walls: A review of opportunities and challenges in research and development. Renewable and Sustainable Energy Reviews 2012;16:6340-51.

[10] TTian T, Zhao CY. A review of solar collectors and thermal energy storage in solar thermal applications. Applied Energy 2013;104:538-53.

[11] dKamel RS, Fung AS. Solar systems and their integration with heat pumps: a review. Energy and buildings 2014.

[12] Chan CW, Ling-Chin J, Roskilly AP. A review of chemical heat pumps, thermodynamic cycles and thermal energy storage technologies for low grade heat utilisation. Applied Thermal Engineering 2013;50:1257-73.

[13] Self SJ, Reddy BV, Rosen MA. Geothermal heat pump systems: Status review and comparison with other. Applied Energy 2013;101:341-48.

[14] Sarbu I, Sebarchievici C. General review of ground-source heat pump systems for heating and cooling of buildings. Energy and buildings 2014;70:441-54.

[15] Din Z, Waqas A. Phase change material (PCM) storage for free cooling of buildings: A review. Renewable and Sustainable Energy Reviews 2013;18:607-25.
[16] Memon SA. Phase change materials integrated in building walls: a state of the art review. Renewable and Sustainable Energy Reviews 2014;31:870-906.

[17] Shalby SM, Bek MA, El-Sebaii AA. Solar dryers with PCM as energy storage medium: A review. Renewable and Sustainable Energy Reviews 2014;33:110-116.

[18] Mardiana-Idayu A, Riffat SB. Review on heat recovery technologies for building applications. Renewable and Sustainable Energy Reviews 2012;16(2):1241-55.

[19] American Society of Heating, Refrigerating and AirConditioning Engineers. ASHRAE handbook of fundamentals, Atlanta: American Society of Heat REF A; 1967, p. 544.

[20] Alario J, Brown R, Kosson R. Monogroove heat pipe design: Insulated liquid channel with bridging wick. Journal of Heat Recovery Systems 1986;6(1).

[21] Hughes BR, Chaudhry HN, Calautit JK. Passive energy recovery from natural ventilation air streams. Applied Energy 2014;113:127-140.

[22] Riffat SB, Warren AP, Webb RA. Rotary heat pump driven by natural gas. Heat Recovery Systems and CHP 1995;15(6):545-54.

[23] Vali A, Simson CJ, Besant RW, Mahmood G. Numerical model and effectiveness correlations for a run-around heat recovery system with combined counter and cross flow exchangers. International Journal of Heat and Mass Transfer 2009;52(256):5827-40.

[24] Joen CT, Park Y, Wang Q, Sommers A, Han X, Jacobi A. A review on polymer heat exchangers for HVAC\&R applications. International Journal of Refrigeration 2009;32(5):763-79.

[25] Zweben C, Fellow S. Emerging high-volume applications for advanced thermally conductive materials. Proceedings from the 49th International Symposium and Exhibition: Long Beach, 2004.

[26] Zaheed L, Jachuck RJJ. Review of polymer compact heat exchangers, with special emphasis on a polymer film unit. Applied Thermal Engineering 2004;24(16):2323-58.

[27] Norley J. Graphite heatsinks: Like copper without the weight: Parma; 2005.

[28] Liu B, Chen J, Du X, Xue L. Poly (vinyl chloride)/montmorillonite hybrid membranes for total-heat recovery ventilation. Journal of Membrane Science 2013;443:8392.

[29] Kragh J, Rose J, Nielsen TR, Svendsen S. New counter flow heat exchanger designed for ventilation systems in cold climates. Energy and Buildings 2007;39(11):1151-8.

[30] Fouih YE, Stabat P, Rivière P, Hoang P, Archambault V. Adequacy of air-to-air heat recovery ventilation system applied in low energy buildings. Energy and Buildings 2012;54:29-39. 
[31] Roulet CA, Heidt FD, Foradini F, Pibiri MC. Real heat recovery with air handling units. Energy and Buildings 2001;33(5): 495502 .

[32] Nassif N. A robust CO2-based demand-controlled ventilation control strategy for multi-zone HVAC systems. Energy and Buildings 2012;45:72-81.

[33] KMC Controls. Demand Control Ventilation Benefits for Your Building. 2013:1-6.

[34] Nga MO, Qua M, Zhengb P, Lib Z, Hang Y. CO2-based demand controlled ventilation under new ASHRAE Standard 62.1-2010: A case study for a gymnasium of an elementary school at West Lafayette, Indiana. Energy and Buildings 2011;43(11):3216-25.

[35] Lu T, Lü X, Viljanen M. A novel and dynamic demandcontrolled ventilation strategy for $\mathrm{CO} 2$ control and energy saving in buildings. Energy and Buildings 2011;43(9):2499-508.

[36] Shan K, Sun Y, Wang S, Yan C. Development and In-situ validation of a multi-zone demand-controlled ventilation strategy using a limited number of sensors. Building and Environment 2012;57:28-37

[37] Sun Z, Wang S, Ma Z. In-situ implementation and validation of a $\mathrm{CO} 2$-based adaptive demand-controlled ventilation strategy in a multi-zone office building. Buildings and Environment 2011;46(1):124-33

[38] Johansson D, Bagge H, Lindstrii L. Measurements of occupancy levels in multi-family dwellings: Application to demand controlled ventilation. Energy and Buildings 2011;43(9):2449-55.

[39] Fan Y, Kameishi K, Onishi S, Ito K. Field-based study on the energy-saving effects of $\mathrm{CO} 2$ demand controlled ventilation in an office with application of energy recovery ventilators. Energy and buildings 2014;68:412-22.

[40] Watanabe S, Melikov AK, Knudsen GL. Design of an individually controlled system for an optimal thermal microenvironment. Building and Environment 2010;45(3):54958.

[41] Bisoniya TS, Kumar A, Baredar P. Experimental and analytical studies of earth-air heat exchanger (EAHE) systems in India: A review. Renewable and Sustainable Energy Reviews 2013;19:238-46.

[42] Brake J. Old technology for new buildings, a study on earth-to-air heat exchangers. Eindhoven: University of Technology Eindhoven; 2008.

[43] Milun S, Kilić T, Bego O. Measurement of Soil Thermal Properties by Spherical Probe. IEEE Transactions on Instrumentation and Measurement 2005;54(3).

[44] Austin WA, Yavuztruk C, Spitler JD. Development of an in-situ system and analysis procedure for measuring ground thermal properties. Denver; 2000.

[45] Acuña J, Palm B. Distributed Thermal Response Test on a U-pipe Borehole Heat Exchanger. Applied Energy 2013;109:312-20.

[46] Xaman ., Hernandez-Perez I, Arce J, Alvarez G, Ramirez-Davila L, Noh-Pat F. Numerical study of earth-to-air heat exchanger: the effect of thermal insulation. Energy and buildings 2014;85:35661.

[47] Zhao MZ. Simulation of earth-to-air heat exchanger systems. Montreal: Concordia University;2004.

[48] Vlad GE, Ionescu C, Necula H, Badea A. Thermoeconomic Design of an Earth to Air Heat Exchanger Used to Preheat Ventilation Air in Low Energy Buildings. Conference proceedings Recent researches in energy, environment, entrepreneurship, innovation. Bucharest; 2011.

[49] Bansal V, Misra R, Agrawal GD, Mathur J. Performance analysis of earth-pipe-air heat exchanger for winter heating. Energy and Buildings 2009; 41(11):1151-4

[50] Gan G. Dynamic interactions between the ground heat exchanger and environments in earth-air tunnel ventilation of buildings. Energy and buildings 2014;85:12-22.

[51] Givoni B. Passive and low energy cooling of buildings. New York: John Wiley \& Sons; 1994, p. 272.

[52] Ge H, Li H, Mei S, Liu J. Low melting point liquid metal as a new class of phase change material: An emerging frontier in energy area. Renewable and Sustainable Energy Reviews 2013;21:331-46.

[53] Alwadhi EM, Alqallaf HJ. Building roof with conical holes containing PCM to reduce the cooling load: Numerical study. Energy 2011;52(8-9):2958-64.

[54] Gracia A, Navarro L, Castell A, Ruiz-Pardo Á, Alvárez S, Cabeza LF. Experimental study of a ventilated facade with PCM during winter period. Energy and Buildings 2013;58:324-32.
[55] Sayyar M, Weerasiri RR, Soroushian P, Lu J. Experimental and numerical study of shape-stable phase-change nanocomposite toward energy-efficient building constructions. Energy and buildings 2014;75:249-55.

[56] Soares N, Costa JJ, Gaspar AR, Santos P. Review of passive PCM latent heat thermal energy storage systems towards buildings' energy efficiency. Energy and Buildings 2013;59:82103.

[57] Parameshwaran R, Harikrishnan S, Kalaiselvam S. Energy efficient PCM-based variable air volume air conditioning system for modern buildings. Energy and Buildings 2010;42(8):135360

[58] Lopez JPA, Kuznik F, Baillis D, Virgone J. Numerical modeling and experimental validation of a PCM to air heat exchanger. Energy and Buildings 2013;64:415-22.

[59] Aroul-Raj VA, Velraj R. Review on free cooling of buildings using phase change materials. Renewable and Sustainable Energy Reviews 2010;14(9):2819-29.

[60] Wang F, Maidment G, Missenden J, Tozer R. A review of research concerning the use of PCMS in air conditioning and refrigeration engineering. Advances in Building Technology 2002;2(2):1273-80

[61] Agyenim F, Eames P, Smyth M. Experimental study on the melting and solidification behaviour of a medium temperature phase change storage material. Renewable Energy 2011;36(1):108-17.

[62] Ismail KAR, Alves CLF, Modesto MS. Numerical and experimental study on the solidification of PCM around a vertical axially finned isothermal cylinder. Applied Thermal Engeneering 2001;21(1):53-77.

[63] A. Erek et al. Experimental and numerical investigation of thermal energy storage with a finned tube. Fuel and Energy Abstracts 2005;47(2):114.

[64] Trelles JP, Dufly JJ. Numerical simulation of porous latent heat thermal energy storage for thermoelectric cooling. Applied Thermal Engineering 2003;23.

[65] Hoogendoorn CJ, Bart GCJ. Performance and modelling of latent heat stores. Solar Energy 1992;48(1).

[66] Velraj R, Seeniraj RV, Hafner B, Faber C, Scwharzer K. Heat transfer enhancement in a latent heat storage system. Solar Energy 1999;65(3).

[67] Pielichowska K, Pielichowskai K. Phase change materials for thermal energy storage. Progress in materials science 2014;65:67123.

[68] Kalogirou S. Solar thermal collectors and applications. Progress in Energy and Combustion Science 2004;30(3):231-95.

[69] Ryan D, Burek SAM. Experimental study of the influence of collector height on the steady state performance of a passive solar air heater. Solar Energy 2010;84:1676-84

[70] Zhang Z, Sun Z, Duan C. A new type of passive solar energy utilization technology - the wall implanted with heat pipes. Energy and buildings 2014;84:111-6.

[71] Haghighi AP, Maerefat M. Solar ventilation and heating of buildings in sunny winter days using solar chimney. Sustainable Cities and Society 2014;10:p.72-9.

[72] Lambic M, Dragićević S. Influence of constructive and operating parameters on a modified Trombe wall efficiency. Archives of Civil and Mechanical Engineerign 2011;11(4):825-38.

[73] Hami K, Draoui B, Hami O. The thermal performances of a solar wall. Energy 2012;39:11-6.

[74] Jaber S, Ajib S. Optimum design of Trombe wall system in mediterranean region. Solar Energy 2011;85:1891-8.

[75] Krüger E, Suzuki E, Matoski A. Evaluation of a Trombe wall system in a subtropical location. Energy and Buildings 2013;66:364-72

[76] Fiorito F. Trombe walls for lightweight buildings in temperate and hot climates. Exploring the use of phase-change materials for performances improvement. Energy Procedia 2012;30:1110-9.

[77] Quesada G, Rousse D, Dutil Y, Badache M, Hallé S. A comprehensive review of solar facades. Opaque solar facades. Renewable and Sustainable Energy Reviews 2012;16:2820-32.

[78] Gracia A, Navarro L, Castelli A, Ruiz-Pardo Á, Álvarez S, Cabeza LF. Solar absorption in a ventilated facade with PCM. Experimental results. Energy Procedia 2012;30:986-94.

[79] Quesada G, Rousse D, Dutil Y, Badache M, Hallé S. A comprehensive review of solar facades. Transparent and translucent solar facades. Renewable and Sustainable Energy Reviews 2012;16:2643-51. 
[80] López FP, Jensen RL, Heiselberg P, Santiago MRA. Experimental analysis and model validation of an opaque ventilated facade. Building and Environment 2012;56:265-75.

[81] Zhou J, Chen Y. A review on applying ventilated double-skin facade to buildings in hot-summer and cold-winter zone in China. Renewable and Sustainable Energy Reviews 2010;14(4):1321-8.

[82] Carlos JS, Corvacho H, Silva PD, Gomes JPC. Real climate experimental study of two double window systems with preheating of ventilation air. Energy and Buildings 2010;42:92834.

[83] Carlos JS, Corvacho H, Silva PD, Gomes JPC. Heat recovery versus solar collection in a ventilated double window. Applied Thermal Engineering 2012;37:258-66.

[84] Carlos JS, Corvacho H, Silva PD, Gomes JPC. Modelling and simulation of a ventilated double window. Applied Thermal Engineering 2011;31:93-102.

[85] Cordeau S., Barrington S.. Performance of unglazed solar ventilation air pre-heaters for boiler barns. Solar energy 2011;85(7):1418-29.

[86] Latvijas Republikas Ministru Kabinets. Noteikumi par Latvijas būvnormatīvu LBN 231-03 "Dzīvojamo un publisko ēku apkure un ventilācija”. Latvijas Vēstnesis 2003;132(2897).

[87] Bharat Tanks and Vessels

http://www.bharattanksandvessel.com/pressure-vessels-and-pressureequipments.html. [Accessed 25.07.2013].

[88] Upp EL, LaNasa PL. Fluid Flow Measurement: A Practical Guide to Accurate Flow Measurement. 2nd ed. Burlington MA: Gulf Publishing Company; 2002, p. 275.

[89] Cheng LH, Zhang L, Chen HL, Gao CJ. Hollow fiber contained hydrogel-CA membrane contactor for carbon dioxide removal from the enclosed spaces. Journal of Membrane Science 2008;324(1-2):33-43.

[90] Wörmeyer K, Smirnova I. Adsorption of CO2, moisture and ethanol at low partial pressure using aminofunctionalised silica aerogels. Chemical Engineering Journal 2013;225:350-7.

[91] Mattox EM, Knox JC, Bardot DM. Carbon dioxide removal system for closed loop atmosphere revitalization, candidate sorbents screening and test results. Acta Astronautica 2013;86:39-46.

[92] Jones HW, Kliss MH. Exploration life support technology challenges for the Crew Exploration Vehicle and future human missions. Advances in Space Research 2010;45(7):917-28.

[93] Aydogan-Cremaschi S, Orcun S, Blau G, Pekny JF, Reklaitis GV. A novel approach for life-support-system design for manned space missions. Acta Astronautica 2009;65(3-4):330-46.

[94] Yadav AS, Bhagoria JL. Heat transfer and fluid flow analysis of solar air heater: A review of CFD approach. Renewable and Sustainable Energy Reviews 2013;23:60-79.

[95] Esakkimuthu S, Hassabou AH, Palaniappan D, Spinnler M, Blumenberg J, Velraj R. Experimental investigation on phase change material based thermal storage system for solar air heating applications. Solar Energy 2013;88:144-53.

[96] Oztop HF, Bayrak F, Hepbasli A. Energetic and exergetic aspects of solar air heating (solar collector) systems. Renewable and Sustainable Energy Reviews 2013;21:59-83.

[97] $\mathrm{Hu} J$, Sun X, Xu J, Li Z. Numerical analysis of mechanical ventilation solar air collector with internal baffles. Energy and Buildings 2013;62:230-8.

[98] Patil AK. Heat transfer mechanism and energy efficiency of artificially roughened solar air heaters - a review. Renewable and sustainable energy reviews 2014;42:681-9.

[99] Zhao DL, Li Y, Dai YJ, Wang RZ. Optimal study of a solar air heating system with pebble bed energy storage. Energy conversion and management 2014;52:2392-400.

[100] Yadav AS, Bhagoria JL. A CFD based thermo-hydraulic performance analysis of an artificially roughened solar air heater having equilateral triangular sectioned rib roughness on the absorber plate. International jpurnal of heat and mass transfer 2014;70:1016-39.

[101] Gopalakrishnan K, Khaitan SK, Kalogirou S, editors. Soft Computing in Green and Renewable Energy Systems, Iowa: Springer; 2011

[102] Letcher TM, editor. Future Energy. Improved, Sustainable and Clean Options for Our Planet. 2nd ed. London: Elsevier; 2014.

[103] Noro M, Lazzarin RM, Busato F. Solar cooling and heating plants: An energy and economic analysis of liquid sensible vs phase change material (PCM) heat storage. International journal of refrigeration 2014;39:104-116.
[104] Saman W, Bruno F, Halawa E. Thermal performance of PCM thermal storage unit for a roof integrated solar heating system. Solar Energy 2004;78(2):341-9.

[105] Charvat P, Klimeš L, Ostry M. Numerical and experimental investigation of a PCM-based thermalstorage unit for solar air systems. Energy and Buildings 2014;68:488-97.

[106] Chow TT, Tiwari GN, Menezo C. Hybrid Solar: A Review on Photovoltaic and Thermal Power Integration. International Journal of Photoenergy 2012;2012:17.

[107] Zhang X, Zhao X, Smith S, Xu J, Yu X. Review of R\&D progress and practical application of the solar photovoltaic/thermal (PV/T) technologies. Renewable and Sustainable Energy Reviews 2013;16(1):599-617.

[108] Moradi K, Ebadian MA, Lin CX. A review on PV/T technologies: Effects of control parameters. International Journal of Heat and Mass Transfer 2013;64:483-500.

[109] Assoa YB, Menezo C. Dynamic study of a new concept of photovoltaic-thermal hybrid collector. Solar energy 2014;107:637-52.

[110] Lin W, Ma Z, Sohel I, Cooper P. Development and evaluation of a ceiling ventilation system enhanced by solar photovoltaic thermal collectors and phase change materials. Energy conversion and management 2014;88:218-230.

[111] O'Neal D, Bryant J. Performance Analysis of a Ventilation Air Heat Pump. ASHRAE Transactions 2010;116:168-75.

[112] McQuiston FC, Parker JD, Spitler JD. Heating, Ventilating, and Air Conditioning Analysis and Design. 6th ed. Oklahoma: John Wiley \& Sons; 2005.

[113] Real A., Garcia V., Domenech L., Renau J., Montes N., Sanchez G. Improvement of a heat pump based HVAC system with PCM thermal storage for cold accumulation and heat dissipation. Energy and buildings 2014;83:108-16.

[114] Jung HW, Kang H, Yoon WJ, Kim Y. Performance comparison between a single-stage and a cascade multi-functional heat pump for both air heating and hot water supply. International Journal of Refrigeration 2013;36(5):1431-41.

[115] Nguyen A, Kim Y, Shin Y. Experimental study of sensible heat recovery of heat pump during heating and ventilation. International Journal of Refrigeration 2005;28(2):242-52.

[116] Omer A. Ground-source heat pumps systems and applications. Renewable and Sustainable Energy Reviews 2008;12(2):344-371.

[117] Fracastoro GV, Serraino M. Energy analyses of buildings equipped with exhaust air heat pumps (EAHP). Energy and Buildings 2010;42(8):1283-89.

[118] Calay RK, Wang WC. A hybrid energy efficient building ventilation system. Applied Thermal Engineering 2013;57(12):7-13.

[119] Zwang CH, Haiyan W, Dexing S. Design Principle of Hydraulic and Continuous Filter Regeneration Equipment. Proceedings from the 3rd International Conference on Measuring Technology and Mechatronics Automation: Shangshai; 2011.

[120] Zhuang Zy, Zhang Ch, Mu K, Sun DX. The frequency conversion technology on the sewage source heat pump system. Proceedings from the 5th International workshop on energy and environment of residential buildings and 3rd International conference on built environment and public health: Guilin; 2009.

[121] Xue-Hui W, De-Xing S. Thermodynamic evaluation on heat exchanger applied for untreated urban sewage. Proceedings from Renewable Energy Resources: Harbin; 2007.

[122] HUBER Technology, "Heating and cooling with wastewater," 2012.

http://www.huber.de/fileadmin/02_Loesungen/08_Waerme_aus Abwasser/02_Waerme_aus_dem_Kanal_ThermWin/Prospekt/wa ermerueckgewinnung en.pdf [15/07/2013].

[123] Davidsson H, Bernardo LR, Larsson S. Design and performance of a hybrid ventilation system with heat recovery for low energy buildings. Journal of Environment and Engineering 2011; 6:46977.

[124] Liu L, Fu L, Jiang Y. Application of an exhaust heat recovery system for domestic hot water. Energy 2010;35(3):1476-81.

[125] Liu X, Ni L, Lau SK, Li H. Performance analysis of a multifunctional Heat pump system in heating mode. Applied Thermal Engineering 2013;51(1-2):698-710.

[126] Busato F, Lazzarin RM, Noro M. Two years of recorded data for a multisource heat pump system: A performance analysis. Applied Thermal Engineering 2013;57(1-2):39-47.

[127] Ploskić A, Holmberg S. Low-temperature ventilation pre-heater in combination with conventional room heaters. Energy and Buildings 2013;65:248-59. 
[128] Rad FM, Fung AS, Leong WH. Feasibility of combined solar thermal and ground source heat pump systems in cold climate, Canada. Energy and Buildings 2013;61:224-32.

[129] Li QY, Chen Q, Zhang X. Performance analysis of a rooftop wind solar hybrid heat pump system for buildings. Energy and Buildings 2013;65:75-83.

[130] Mardiana A, Riffat SB. Review on physical and performance parameters of heat recovery systems for building applications. Renewable and Sustainable Energy Reviews 2013;28:174-190.

[131] GhaffarianHoseini AH, Dahlan ND, Berardi U, GhaffarianHoseini A, Makaremi N, GhaffarianHoseini M, Sustainable energy performances of green buildings: A review of current theories, implementations and challenges. Renewable and Sustainable Energy Reviews 2013;25:1-17.

[132] Santos RR Hugo, Leal MS Vitor. Energy vs. ventilation rate in buildings: A comprehensive scenario-based assessment in the European context. Energy and Buildings 2012;54:111-121.

[133] Fabricio E, Seguro F, Filippi M. Integrated HVAC and DHW production systems for Zero Energy

Buildings. Renewable and Sustainable Energy Reviews 2013; 2014;40:515-541.

[134] Lewis M. Integrated design for sustainable buildings. ASHRAE J 2004;46(9):22-30. 